Article

\title{
Secular Volunteerism among Texan Emerging Adults: Exploring Pathways of Childhood and Adulthood Religiosity
}

\author{
Reed T. DeAngelis *, Gabriel A. Acevedo and Xiaohe Xu \\ Department of Sociology, University of Texas at San Antonio, One UTSA Circle, San Antonio, TX 78249, USA; \\ gabriel.acevedo@utsa.edu (G.A.A.); xiaohe.xu@utsa.edu (X.X.) \\ * Correspondence: Reed.DeAngelis@utsa.edu; Tel.: +1-210-410-7550
}

Academic Editor: Patricia Snell Herzog

Received: 31 January 2016; Accepted: 2 June 2016; Published: 13 June 2016

\begin{abstract}
Prior research suggests that religiosity, especially public religious participation, is related to greater volunteerism. However, less is known about religious transmission across the life course, in particular whether and how religiosity in childhood is linked to later life volunteerism. This study investigates a sample of emerging adults in South Texas $(n=701)$ with a high percent of Hispanic Americans (53 percent). Specifically, we examine pathways of childhood and emerging adulthood religiosity leading to secular volunteerism. Findings indicate that both childhood and emerging adulthood religiosity are associated with greater volunteerism, but the effects of childhood religiosity on emerging adulthood volunteerism are mediated through emerging adulthood religiosity. These findings provide further confirmation of the importance of childhood religiosity only insofar as religiousness persists into adulthood. In other words, we find that it is emerging adulthood religiosity that transmits childhood religiosity into greater secular volunteerism in later life. Furthermore, emerging adulthood public religiosity has the most robust direct effects on volunteerism.
\end{abstract}

Keywords: emerging adulthood; volunteerism; religious transmission; social learning theory; Hispanic Americans; race and ethnicity

\section{Introduction}

This study investigates the relationship between volunteerism and religiosity for a sample of emerging adults in South Texas. Grounded in theories of social learning, this study also suggests two potential mechanisms for the volunteerism and religiosity relationship. The first expectation is derived from emerging adulthood studies, from the psychological process described as "recentering" [1], which implies that childhood religiosity will affect later life volunteerism insofar as childhood religious socialization is internalized as an individualized aspect of emerging adult identity, i.e., private religiosity. This expectation is contrary to sociological studies finding forms of social participation are central [2,3], i.e., public religiosity. Thus, this study investigates volunteerism as it relates to life course public and private religiosity.

We contribute to the literature on volunteerism by examining the relationship between religiosity and civic engagement among a sample of emerging adults attending a large public university in South Texas. For our study, emerging adults are operationalized as young adults between the ages of 18 and 29. We explore how emerging adult volunteering is associated with multiple domains of religiosity, net of socio-demographic controls. The high proportion of Hispanic Americans in South Texas also enables an examination of potential racial and ethnic differences in religious transmission across the life course. Based on extant studies finding that African and Asian Americans have high rates of religious transmission across the life course [4,5], we investigate whether these trends also hold in predominantly Hispanic populations. 
Particularly noteworthy, however, is that our study measures two key dimensions of religiousness: (a) public and private forms of religiosity during emerging adulthood; and (b) public and private forms of religiosity during childhood. Theoretically, we draw from work that has conceptualized processes of religious socialization and internalization as "drivers" of civic engagement, as well as social learning theories across the life course. To contextualize our analysis, we first offer an overview of the literature on civic engagement with emphasis on work that has addressed linkages between volunteerism, religion, and emerging adulthood. We also discuss the theoretical frameworks which inform our study. Within this theoretical and empirical context, we subsequently propose an analytical framework with testable hypotheses. We then empirically test our hypotheses and close with a discussion of the implications of this study for understanding emerging adult volunteerism and propose avenues of future research.

\section{Theoretical and Empirical Context of Emerging Adult Volunteerism and Religiosity}

\subsection{Volunteerism}

Civic engagement involves the desire and capacity of individuals to volunteer their resources to various activities accepted as beneficial to common objectives and goals. Some scholars have suggested that civic engagement is a central element of democratic societies, and one that was identified as early as the 18th century in Alexis de Tocqueville's classic Democracy in America [6].

Putnam and colleagues, for instance, have amassed a considerable body of empirical research that, following in de Tocqueville's footsteps, demonstrates how volunteer participation is a keystone of vibrant democratic societies [7-10]. However, critics have questioned Putnam on the grounds that his data is either inaccurate and omits considerable evidence of continuing civic engagement in democratic states [11], or that Putnam fails to account for the changing nature of present-day volunteer activities [12].

Consequently, more recent work has shifted the focus away from broad generalizations linking volunteer participation to macro level social processes such as political systems and culture. Instead, this line of inquiry has explored individual level predictors that may explain propensities to engage in civic volunteering [13]. These studies draw from individual level data to assess relationships between such factors as gender [14-16], race/ethnicity [17,18], socioeconomic status [19,20], educational attainment [21-23] or intersections of these characteristics and propensities to participate in volunteerism $[24,25]$.

Moreover, studies of the life course have shown a positive relationship between age and formal volunteerism - a rather intuitive finding when one considers the greater levels of financial autonomy and spare time that most Americans accumulate as they age [13,17,26,27]. There is also a less developed but growing body of work focused primarily on civic engagement among emerging adults [18,28,29]. However, to date, little work explores possible relationships between volunteerism and religiosity among emerging adults.

\subsection{Volunteerism and Religiosity}

Thus far, one common thread appearing in social scientific research on civic engagement has been the role of religiosity in fostering prosocial behaviors such as volunteering and charitable giving [30-32]. The general consensus is that religiosity motivates and bolsters civic engagement in the form of religious volunteerism and charitable giving [32-34]. Furthermore, findings in this body of work indicate that religiosity also fosters secular volunteerism [35]. Our theoretical arguments are based on the assumption that religious investments, in the form of learned religious norms and practices, can foster both competencies and propensities for civic engagement [36]. It is not surprising that studies of religion have specifically focused on linkages between religion and volunteerism in the United States, a society characterized by both high rates of volunteerism and charitable contributions to religious organizations [37]. The general research finding confirms this pattern, namely, there is a positive 
association between religion and volunteerism [36], while being careful not to generalize to all forms of religiousness [38].

Similar to extant scholarship, we argue that what has been less clearly conceptualized in volunteerism research is the distinction between public (e.g., attending religious services) and private religiosity (e.g., prayer, reading scripture, etc.) [39] and how these distinct forms of religiosity might affect volunteering behaviors [40]. Considerable attention has been given to private forms of religiosity, through a focus on beliefs and psychological dispositions in motivating volunteerism [26,41]. These studies have converged around a series of core insights that are particularly relevant for our study. First, scholars working from a rational choice framework tend to argue that prosocial behaviors are motivated by self-interest over altruistic tendencies [42-44]. This body of work has been criticized on both theoretical $[45,46]$ and empirical $[47,48]$ grounds. Second, a parallel line of work has found positive correlations between psychological wellbeing and volunteerism $[49,50]$. Finally, research has also explored religious belief as a motivating factor in volunteer activities [38,51-53]. This work has repeatedly identified a positive association between religious belief and proclivities to volunteer. While approaching volunteerism from distinct methodological, theoretical, and conceptual avenues, these studies tend to emphasize personal, internalized psychological processes as shaping prosocial and volunteer activities.

In contradistinction, another line of scholarship has taken a less cognitive approach by focusing primarily on public, social, and structural religiosity factors, such as religious participation. Lim and MacGregor, for instance, suggested spillover effects of association with religious communities, whereby even non-religious individuals who reported more friendships with religious individuals displayed a greater propensity to volunteer in both religious and secular organizations [54]. Johnston, drawing from longitudinal data, presented similar findings that reinforced the idea that immersion into religious communities promoted volunteerism over the life course [52]. Furthermore, this religious spillover effect was present irrespective of psychological dispositions. Taken together, these studies represent a body of scholarship that has assessed multifaceted linkages between religion and volunteerism and highlighted moderating factors such as race-ethnicity [24], health and well-being [41,55], age [56], and gender $[29,57]$. From these studies, we incorporate an emphasis on public, extra-individual, and social processes as shaping prosocial and volunteer activities [58].

Combined, we apply the insights of extant studies through a focus on both the personal, individualized forms and the public, social forms of religiosity, as related to volunteerism.

\subsection{Social Learning Theory: The Impact of Childhood Socialization}

Previous studies investigating rates of volunteerism have focused on both personal and public forms of religiosity as related to charitable behaviors [13,32,53]. Related to these studies, we are particularly interested in how childhood religious socialization relates to later life volunteerism. A plausible theoretical mechanism has been proposed by Bandura's social learning theory [59], which suggests that behavior is acquired through observation and emulation of others in social situations. Applied to childhood socialization, social learning theory has been employed to explain processes by which children learn to model their behaviors based on interaction with parents [60,61].

One strand of this research has considered general altruistic behaviors that are (a) transmitted through processes of family socialization (i.e., intergenerational transmission); and (b) translated to service provision in volunteer settings $[62,63]$. In terms of specific volunteering behaviors, a parallel body of work has considered the parental transmission of prosocial behaviors that enhance propensities to become civically engaged. Results drawing from both cross-sectional and panel data support the central tenets of social learning theory and suggest that parents serve as role models who can motivate prosocial volunteer behaviors in both religious and secular settings [64,65].

However, it is also important to note the determinants of family socialization, which include material resources like income, accumulated wealth, and neighborhood quality. For example, some of the empirical studies have emphasized the substantial impediments and challenges to civic engagement 
experienced by low-income families [66,67]. However, results of longitudinal research presented by Lichter and colleagues [68] indicate that lower propensities to volunteer among the economically disadvantaged are offset by socioemotional stability and positive life experiences. While these studies raise important questions for research on the impediments and resources that motivate volunteerism, the current study takes additional determinants into consideration, namely, the role of religion as a possible antecedent of civic engagement.

Growing attention has been paid to "emerging adulthood" (e.g., a new life stage between 18 and 29 years of age) [69-71]. As related to volunteerism, one major study found that increased family and community ties during adolescence predicted an increased rate of civic engagement during emerging adulthood [72]. Echoing Bandura's social learning theory, researchers have noted that unique familial and community environments shape adolescents' and young adults' civic identities [73,74]. To summarize, these studies have established positive linkages between various dimensions of religiosity, ranging from public religious participation to private religious devotion, and civic engagement during adolescence or emerging adulthood [4,5,75-79].

Despite the fact that there has been a growing body of research linking religiosity with volunteerism across the life course, the empirical research on the linkage between childhood religious socialization and propensities to volunteer during emerging adulthood is scant and often indirect $[79,80]$. Applying social learning theories to this study implies two potentials for the volunteerism and religiosity relationship. The first expectation is derived from emerging adulthood studies, from the psychological process described as "recentering" [3], which implies that childhood religiosity will affect later life volunteerism insofar as childhood religious socialization is internalized as an individualized aspect of emerging adult identity, i.e., private religiosity. This expectation is contrary to sociological studies finding forms of social participation are central [4,5], i.e., public religiosity. Thus, this study takes a social learning approach to investigating life course volunteerism as it relates to public and private religiosity in childhood and emerging adulthood.

\section{Conceptual Models: Religious Socialization, Life Course Religiosity, and Volunteerism}

Based on the discussion above, we propose two conceptual models assessing empirical relationships between childhood religious socialization, emerging adult private and public religiosity, and civic volunteerism. In these models, we develop two competing hypotheses. The first is that childhood religiosity will foster emerging adult civic volunteerism through private forms of emerging adult religiosity. We represent this first conceptual model in Figure 1 and propose that the effects of childhood religiosity on emerging adult volunteerism are mediated through emerging adult private religiosity.

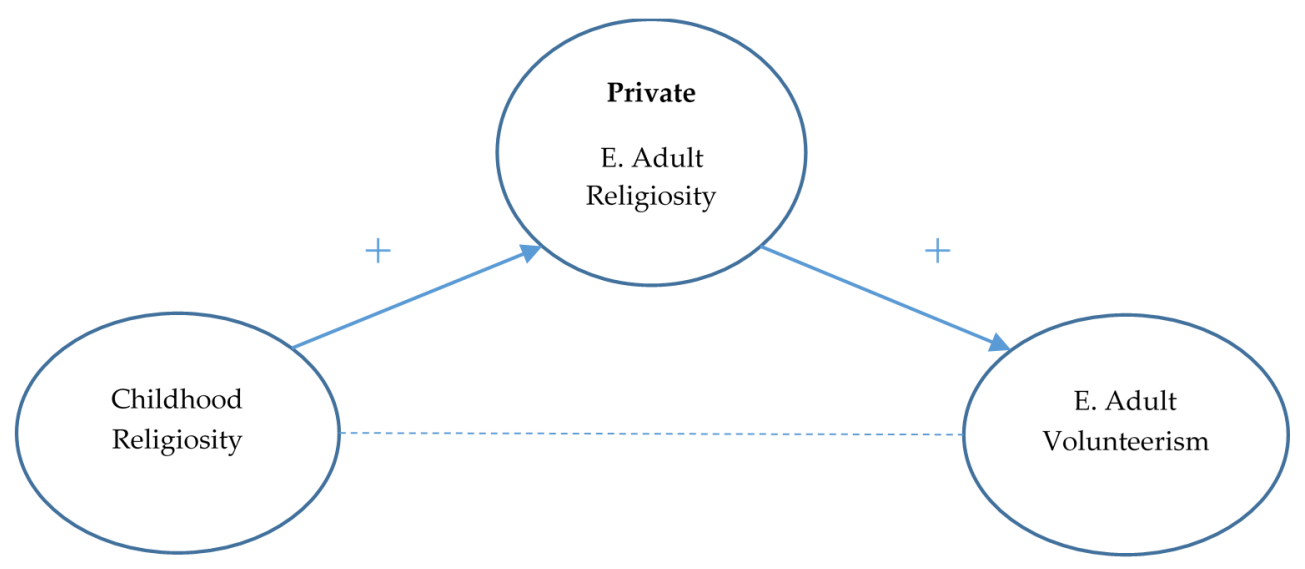

Figure 1. Mediating effects of private emerging adult religiosity on rates of volunteerism. 
In contrast, we propose a second conceptual model in Figure 2 that is also based upon extant literature but with a different theorized expectation. In this alternative hypothesis, we propose that childhood religiosity is also indirectly associated with emerging adult volunteerism through emerging adult religiosity. However, in this model we propose instead that it is mediated through public, social forms of religiosity. Stated differently, childhood religiosity can be translated into emerging adult volunteerism only when childhood religiosity is transmitted into public forms of religiosity during emerging adulthood.

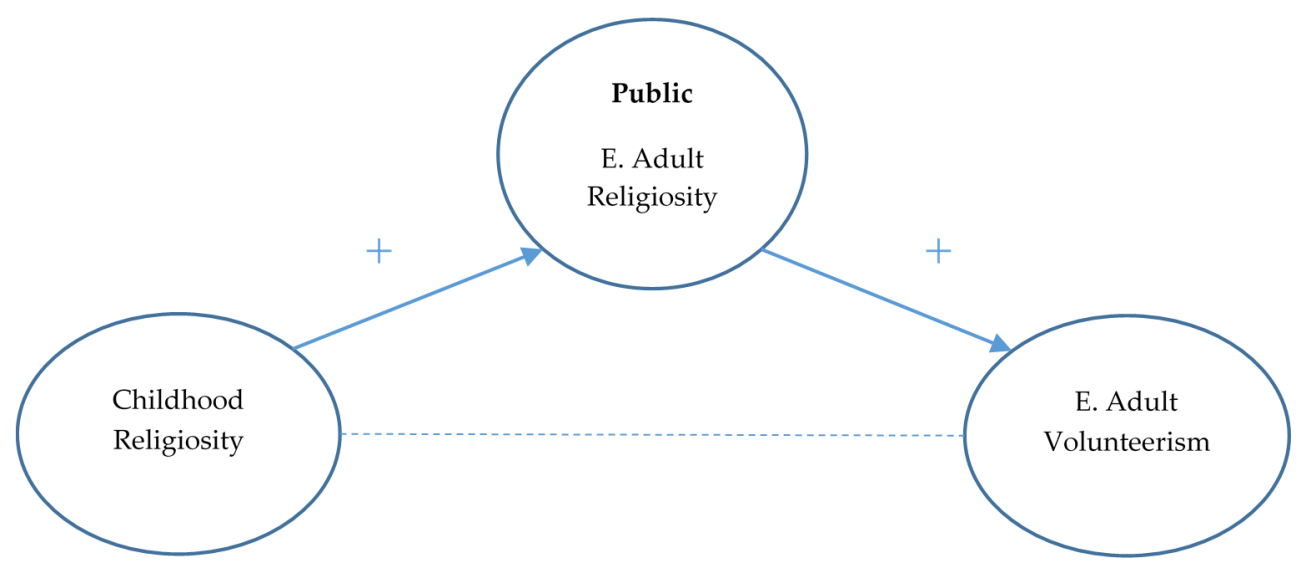

Figure 2. Mediating effects of public emerging adult religiosity on rates of volunteerism.

\section{Research Methods}

\subsection{Data Collection}

The current study analyzes survey data collected from undergraduate students enrolled at the University of Texas at San Antonio (UTSA), a Hispanic-serving, public university located in South Texas. After receiving appropriate human subjects institutional review board (IRB) approvals, students across several colleges completed the self-administered questionnaire on paper before class lectures throughout the 2015 academic year. Students did not receive compensation from either the research team or their professors for completing the survey. Although the data limit the generalizability of our findings, these limitations are somewhat offset by the fact UTSA is characterized by a diverse and nontraditional student body. For instance, two-thirds of the UTSA student population is made up of international students and students from underrepresented minority groups. In addition to the traditional college student age bracket of 18 to 22 years, over one-third of the UTSA student population is aged 23 years and older [81]. In our view the general demographic profile of the UTSA student body provides a unique opportunity to examine the patterns of voluntaristic behavior among less advantaged, college attending emerging adults.

\subsection{Secular Volunteerism Measure}

Emerging adult secular volunteerism was measured via responses to the following survey question, which was subsequently followed by a list of various types of organizations for which one could volunteer: "Over the past 12 months, about how many weeks did you spend doing unpaid volunteer work for the following groups / organizations?" Response categories were ordinal and ranged from " 0 weeks" $=0$, “1-10 weeks" = $1, " 11-20$ weeks" $=2, " 21-30$ weeks" $=3$, , $31-40$ weeks" = 4, and " $41+$ weeks" $=5$. The list of organizations included: (a) health (hospital, hospice, nursing home, mental health unit, clinic, etc.); (b) educational (elementary school, library, tutoring organization, etc.); (c) human service (day car, foster care, meals on wheels, homeless shelter, Red Cross, United Way, women's shelter, family counseling center, etc.); (d) animal welfare/environmental (SPCA, Humane Society, Animal Defense League, Highway Clean-Up, community beautification program, etc.); (e) arts 
and humanities (museum, cultural/ethnic group, public television/radio, etc.); (f) political (political parties, political campaigns, nonpartisan political groups, etc.); (g) youth development (boy/girl scouts, 4-H club, Little League, Big Brothers/Sisters); (h) one-day/short-term service (Day of Caring, Make a Difference Day, MLK Day, Earth Day, etc.); and (i) other. Because the majority of respondents volunteered minimally (i.e., 1-10 weeks in the past year), if at all, the dependent variable was dichotomized such that $1=$ volunteered in the past year, and $0=$ did not volunteer in the past year.

\subsection{Religiosity Measures}

Emerging adult religiosity was assessed through the following measures. Respondents were asked to give their religious affiliation via the following question: "What is your religious preference? Is it Protestant, Catholic, Jewish, some other religion, or no religion?" They were then provided a list of denominations to choose from, which included Baptist, Southern Baptist, Catholic, Episcopalian, Jewish, Latter Day Saint, Lutheran, Methodist, Muslim, Pentecostal, Hindu, Buddhist, none, and other. A follow-up question then listed 14 specific Protestant denominations one could belong to. Respondents' choices were then dummy-coded into four separate variables based on the denominational categories found by Steensland and colleagues [82]. These were Catholic, Conservative Protestant, Mainline Protestant $(=1)$, and other/no religion $(=0)$ as the reference category. Descriptive statistics based on the study sample are displayed in Table 1.

Table 1. Sample characteristics $(n=701)$.

\begin{tabular}{|c|c|c|c|c|}
\hline Variables & $\%$ & Mean & Range & SD \\
\hline \multicolumn{5}{|l|}{ Dependent Variable } \\
\hline Volunteered in Past Year & 69 & - & 0,1 & - \\
\hline \multicolumn{5}{|l|}{ Religious Variables } \\
\hline Public Religiosity & - & 2.13 & 0,8 & 2.10 \\
\hline Private Religiosity & - & 0.88 & 0,4 & 0.86 \\
\hline Childhood Public Religiosity & - & 5.62 & 0,12 & 3.72 \\
\hline Childhood Private Religiosity & - & 7.92 & 0,16 & 4.86 \\
\hline Catholic & 39 & - & 0,1 & - \\
\hline Conservative Protestant & 23 & - & 0,1 & - \\
\hline Mainline Protestant & 10 & - & 0,1 & - \\
\hline Other/None (reference) & 28 & - & 0,1 & - \\
\hline \multicolumn{5}{|l|}{ Covariates } \\
\hline Female & 61 & - & 0,1 & - \\
\hline Male (reference) & 39 & - & 0,1 & - \\
\hline Age & - & 21.54 & 18,29 & 2.44 \\
\hline Married or Cohabitating & 17 & - & 0,1 & - \\
\hline Single (reference) & 81 & - & 0,1 & \\
\hline Employed & 59 & - & 0,1 & - \\
\hline Unemployed (reference) & 42 & - & 0,1 & - \\
\hline White (reference) & 21 & - & 0,1 & - \\
\hline Hispanic & 53 & - & 0,1 & - \\
\hline Black & 15 & - & 0,1 & - \\
\hline Other race & 11 & - & 0,1 & - \\
\hline GPA & - & 3.52 & 0,6 & 1.43 \\
\hline Parents' Education & - & 11.39 & 0,16 & 3.37 \\
\hline Family Social Class & - & 1.69 & 0,3 & 0.71 \\
\hline Year at UTSA & - & 2.50 & 1,4 & 1.14 \\
\hline Fulltime Student & 93 & - & 0,1 & - \\
\hline
\end{tabular}

Emerging adult public religiosity was gauged by responses to two separate questions measuring the frequency of religious attendance at both regular religious services as well as additional church activities outside of regular services. Respondents were asked, "Apart from religious events like weddings, funerals, and baptisms, about how often do you attend religious services (Church, Mosque, Synagogue, etc.)?" and "About how often do you take part in the activities and organizations of a church or place of worship other than attending regular services?" Responses ranged from $0=$ Never 
to $4=$ Several times a week. The two items were then summed together to create an index variable $(\alpha=0.786)$.

Emerging adult private religiosity was indicated by responses to four survey questions measuring frequencies of prayer, reading religious scripture by oneself or with a small group, watching/listening to religious programs on the television/internet/radio, and reading religious material other than scripture. Responses were also coded from $0=$ Never to $4=$ Several times a week. The four items were then averaged to create an index variable $(\alpha=0.780)$.

Childhood religiosity was also measured via two separate index variables measuring both the private $(\alpha=0.890)$ and public $(\alpha=0.860)$ dimensions. For the private dimension of childhood religiosity, respondents were instructed to signify how often they participated in the following religious activities while growing up: (a) receiving religious instruction at home; (b) praying before meals; (c) reading scripture or other religious material; and $(\mathrm{d})$ praying before bedtime. For the public dimension of childhood religiosity, respondents were asked how often they (a) attended church/religious services; (b) attended religious youth groups; and (c) attended "Bible camp" (e.g., religious retreats, religious summer camps, etc.). For both dimensions, responses ranged in values from $0=$ Never to $4=\mathrm{A}$ great deal and were then summed to create two index variables.

\subsection{Control Measures}

Our analyses include a series of standard control variables. These include gender (dummy coded with $1=$ female and $0=$ male); year of age (in years); marital status (dummy coded with $1=$ married $/$ cohabiting and $0=$ single); employment status (dummy coded with $1=$ employed and $0=$ unemployed); race/ethnicity (dummy coded into Hispanic, African American, and other, with white as the reference category); grade point average (ordinal ranging from $0=$ Below 1.5 to $6=$ Above 4.0); mother's and father's educational attainment (ordinal ranging from $0=$ none to $8=$ graduate school and beyond); family social class (ordinal, $0=$ lower class, $1=$ working class, $2=$ middle class, 3 = upper class); year of study at UTSA (ordinal, $1=$ freshman, $2=$ sophomore, $3=$ junior, $4=$ senior); student enrollment status (dummy coded with $1=$ full time and $0=$ part time).

\subsection{Analytical Strategies}

For our outcome measure, we estimate binary logistic regression models with multiple imputation to predict odds of past year secular volunteerism. Our first set of regression models, Models 1-5 in Table 2, examine the direct and independent effects of religious factors on volunteering net of socio-demographic variables. Our second set of models employ structural equation modeling (SEM) to estimate potential mediating effects between religious factors on volunteering (Table 3). Each model includes the effects of two main religious predictors with statistical controls. These models allow for the evaluation of mediation of childhood religiosity and emerging adult volunteerism through two different forms of emerging adult religiosity: public and private. To further investigate these potential mediating effects, we conducted path analysis of direct and indirect effects in accordance with previous literature [83,84]. These results are displayed in Table 4.

\section{Results}

Table 2 presents results of binary logistic regression models predicting odds of past year secular volunteering. Across Models 1-4, results clearly indicate statistically significant and positive associations between all the religious measures and odds of emerging adult volunteerism. However, two findings are particularly noteworthy. First, emerging adult public religiosity is the only religious dimension to maintain statistical significance in Model 5, once all the other religious measures are included simultaneously. Substantively, this model indicates that a one unit increase in public religiosity predicts significantly greater odds of past year secular volunteerism by a factor of 1.240 or 24 percent, even after controlling for sociodemographic variables and religious covariates. Second, the measures of childhood religiosity are no longer statistically significantly related to emerging adult volunteerism 
in Model 5, which suggests potential mediation effects of emerging adulthood religiosity. Next we turn to the results of Table 3.

Table 2. Binary logistic regression models predicting odds of past year secular volunteerism.

\begin{tabular}{|c|c|c|c|c|c|}
\hline Variables & (1) & (2) & (3) & (4) & (5) \\
\hline \multicolumn{6}{|l|}{ Religious Variables } \\
\hline Public religiosity & $1.268^{* * *}$ & - & - & - & $1.253^{* *}$ \\
\hline Private religiosity & - & $1.473^{* *}$ & - & - & 0.999 \\
\hline Childhood public religiosity & - & - & $1.107^{* *}$ & - & 1.033 \\
\hline Childhood private religiosity & - & - & - & $1.052 * *$ & 0.989 \\
\hline \multicolumn{6}{|l|}{ Sociodemographic/Control Variables } \\
\hline Female & $1.691 * *$ & $1.649 * *$ & $1.620 * *$ & $1.649 * *$ & $1.661^{* *}$ \\
\hline Age & 0.925 & 0.926 & 0.959 & 0.933 & 0.959 \\
\hline Married or Cohabitating & 1.185 & 1.110 & 1.084 & 1.143 & 1.129 \\
\hline Employed & $1.495 *$ & 1.444 & 1.287 & 1.439 & 1.363 \\
\hline Hispanic & 1.082 & 1.082 & 1.225 & 1.068 & 1.221 \\
\hline Black & 0.947 & 0.880 & 0.937 & 0.841 & 1.029 \\
\hline Other race & 2.008 & 2.126 & 2.054 & 2.252 & 1.854 \\
\hline GPA & 1.079 & 1.090 & 1.065 & 1.089 & 1.082 \\
\hline Parents' education & 1.035 & 1.028 & 1.019 & 1.019 & 1.036 \\
\hline Family social class & 0.886 & 0.918 & 0.913 & 0.911 & 0.889 \\
\hline Year at UTSA & 0.812 & $0.789 *$ & $0.757^{* *}$ & $0.782 *$ & 0.768 * \\
\hline Full-time student & 0.511 & 0.541 & 0.656 & 0.562 & 0.614 \\
\hline Catholic & 0.853 & 0.929 & 0.927 & 0.941 & 0.848 \\
\hline Mainline Protestant & 0.888 & 0.897 & 0.871 & 0.906 & 0.857 \\
\hline Conservative Protestant & 1.046 & 1.171 & 1.360 & 1.320 & 1.025 \\
\hline Likelihood ratio $\chi^{2}$ & $68.39 * * *$ & $54.87^{* * *}$ & $45.06^{* * *}$ & $50.83^{* * *}$ & $63.61^{* * *}$ \\
\hline$d f$ & 16 & 16 & 16 & 16 & 19 \\
\hline$n$ & 701 & 701 & 701 & 701 & 701 \\
\hline
\end{tabular}

Table 3. Direct effects of emerging adulthood religiosity in logistic regression models using SEM ${ }^{\text {a }}$.

\begin{tabular}{|c|c|c|c|c|}
\hline Variables & (1) & (2) & (3) & (4) \\
\hline \multicolumn{5}{|l|}{ Religious Variables } \\
\hline Public religiosity & $1.247^{* * *}$ & $1.261^{* * *}$ & - & - \\
\hline Private religiosity & - & - & $1.358 *$ & $1.367 *$ \\
\hline Childhood public religiosity & 1.024 & - & 1.051 & - \\
\hline Childhood private religiosity & - & 1.006 & - & 1.026 \\
\hline \multicolumn{5}{|l|}{ Sociodemographic/Control Variables } \\
\hline Female & $1.655^{* *}$ & $1.572 * *$ & $1.572^{* *}$ & $1.611^{* *}$ \\
\hline Age & 0.959 & 0.951 & 0.951 & 0.955 \\
\hline Married or Cohabitating & 1.130 & 1.078 & 1.076 & 1.067 \\
\hline Employed & 1.365 & 1.311 & 1.301 & 1.313 \\
\hline Hispanic & 1.215 & 1.222 & 1.221 & 1.180 \\
\hline Black & 1.004 & 0.919 & 0.936 & 0.844 \\
\hline Other race & 1.854 & 1.987 & 1.985 & 1.906 \\
\hline GPA & 1.082 & 1.073 & 1.074 & 1.075 \\
\hline Parents' education & 1.035 & 1.025 & 1.026 & 1.025 \\
\hline Family social class & 0.893 & 0.922 & 0.920 & 0.932 \\
\hline Year at UTSA & $0.766^{*}$ & $0.759 *$ & $0.762 *$ & $0.753 *$ \\
\hline Full-time student & 0.618 & 0.645 & 0.648 & 0.649 \\
\hline Catholic & 0.845 & 0.895 & 0.910 & 0.908 \\
\hline Mainline Protestant & 0.858 & 0.855 & 0.857 & 0.879 \\
\hline Conservative Protestant & 1.019 & 1.122 & 1.126 & 1.166 \\
\hline$d f$ & 17 & 17 & 17 & 17 \\
\hline$n$ & 701 & 701 & 701 & 701 \\
\hline
\end{tabular}

${ }^{\text {a }}$ Odds coefficients reported; ${ }^{*} p<0.05 ;{ }^{* *} p<0.01 ;{ }^{* * *} p<0.001$. 
Following previous methodological strategies and findings on volunteerism $[84,85]$, we highlight the mediating effects of emerging adulthood public and private religiosity using SEM. Table 4 features unstandardized direct, indirect and total effects of path decomposition analysis. As seen in Table 4, emerging adult public religiosity significantly mediates the effects of childhood religiosity and adult private religiosity. This is indicated by the fact that the direct effects are statistically insignificant while indirect effects are highly statistically significant in the path models. These results confirm our prior observation that both public and private emerging adult religiosity mediate the relationship between childhood religiosity and emerging adult volunteerism, and public emerging adult religiosity has the most direct and robust effect.

Table 4. Path analysis of mediation effects using SEM.

\begin{tabular}{llcc}
\hline Variables & Direct Effect & \multicolumn{1}{l}{ Indirect Effect } & Total Effect \\
\hline & \multicolumn{4}{l}{ Mediator: Public Religiosity } \\
\hline Private Religiosity & -0.001 & $0.186^{* * *}$ & $0.185^{* *}$ \\
Childhood Public Religiosity & 0.046 & $0.108^{* * *}$ & $0.155^{* *}$ \\
Childhood Private Religiosity & 0.016 & $0.121^{* * *}$ & $0.137^{* *}$ \\
\hline & Mediator: Private Religiosity \\
\hline Childhood Public Religiosity & 0.050 & $0.101^{* * *}$ & $0.151^{* *}$ \\
Childhood Private Religiosity & 0.067 & $0.066^{* * *}$ & $0.133^{* *}$ \\
\hline
\end{tabular}

${ }^{*} p<0.05 ;{ }^{* *} p<0.01 ;{ }^{* * *} p<0.001$.

We close this section by briefly emphasizing some noteworthy effects of control measures. First, we find no significant effects of race-ethnicity or religious affiliation on emerging adult volunteerism. Next, we observe that female students show higher odds of volunteering in the past year compared with their male counterparts. Finally, year at UTSA decreases odds of past year volunteerism. This could be due to increasing academic and non-academic obligations.

\section{Discussion and Conclusions}

Our analysis contributes to the growing literature exploring linkages between religious factors and civic engagement. Whereas previous work has often focused on civic engagement in later stages of life, we focus on volunteerism during the formative years of emerging adulthood. Young adults in higher educational settings are often faced with a series of competing interests that motivate and modify behavioral choices in the absence of direct parental supervision. Moreover, it is at this stage of the life course that young adults can go through a process of re-centering wherein they explore their religious identity and formulate and solidify their own religious beliefs in addition to or independent of their familial religious traditions [3]. At the most general level, our results support existing findings that religiosity is related to prosocial behaviors among emerging adults. In addition, our results extend previous scholarship in two important ways.

First, while this study surmises the important role of childhood religious socialization on civic engagement, our findings suggest that religious upbringings are important insofar as they are translated to emerging adult religiosity. As we surmised, childhood religious socialization is positively associated with both forms of emerging adult religiosity. This confirms prior research finding that religious engagement during childhood influences levels of religiosity in later life [1,2]. Our results reinforce this general association and are consistent with social learning theory, which explicates the impact of childhood experiences on later behavioral outcomes. However, unlike prior studies we do not find any distinguishable differences by race and ethnicity.

Second, our study shows a more robust direct effect of public religiosity in emerging adulthood than private religiosity. This means that while internalized religious factors, such as individualized religious devotions, are predictive of civic engagement, it is the social expression of religiosity, such 
as religious participation, that is most unwaveringly linked with propensities to volunteer among emerging adults attending a large public university in South Texas. This finding is also consistent with previous work that underscores the importance of religious social capital as a pathway to volunteering [86,87]. We view this result as potentially explained by recent studies suggesting that emerging adults who regularly engage in religious activities with fellow congregants are provided additional opportunities to volunteer in secular civic activities. As such, these religious associations and friendship ties developed among regular congregants can motivate emerging adults to volunteer with anticipated socio-religious rewards. Furthermore, within a higher education setting, there might be an institutional "cross-pollination" in that student organizations typically cooperate and share volunteer opportunities with one another. Therefore, students who do not attend religious activities may be unaware that these additional volunteer opportunities exist. Additionally, as multiple studies have shown, religious organizations may promote specific skills and competencies (e.g., public speaking, fundraising strategies, and leadership capabilities) that can be translated to success in secular settings $[88,89]$.

\subsection{Interpreting Mediation of Childhood Religiosity}

Given that our study finds emerging adult religiosity mediates the relationship between childhood religiosity and emerging adult volunteerism, this raises the question: What can explain the prominence of adulthood religiosity over childhood socialization? To answer this question, we suggest two plausible mechanisms.

First, students might abandon or become less committed to religious activities while in college $[90,91]$. In this case, students will no longer be embedded in religious communities and, consequently, may no longer be exposed to volunteer opportunities. On the other hand, students might be introduced to new religious organizations upon entering college. This is particularly likely considering the institutional context where our data collection took place. Our study site is characterized by the presence of strong, active religious student organizations and visible on-campus proselytizing efforts. It is therefore quite likely that less religious and non-affiliated students would be presented with religious options when choosing from various on-campus organizational opportunities. In short, this line of reasoning suggests that the university setting may be a unique case in which emerging adults encounter a diverse marketplace of ideas, organizations and alternate worldviews that may at times conflict with childhood religious socialization [92,93].

Secondly, there is reason to suspect that childhood religious socialization is a product of family dynamics. Stated simply, parents often make religious choices on behalf of their children who are then expected to participate irrespective of personal desires. Once becoming adults, individuals begin to voluntarily make personal choices that include either opting in or out of one's familial religious traditions. Therefore, childhood religious experiences should only matter to the extent that they are carried over into emerging adulthood. When these experiences do carry over, we should expect this to result in continued religiosity and increased civic engagement.

\subsection{Conclusions}

To summarize, our study findings resonate primarily with two theoretical perspectives. First of all, the strong association between childhood and emerging adulthood religiosity confirms many of the central tenets of social learning theory. As implied by the path analysis in Table 4, the greater the level of childhood religious socialization, the greater the level of emerging adulthood religiosity. As social learning theorists have argued, the behavioral and attitudinal patterns established in childhood carry over into adulthood and shape outcomes in later life. Second, emerging adult involvement in religious services and activities is the most robust factor mediating involvement with volunteer organizations. In essence, religious participation can be seen as a property of social structure external to individual cognition, which helps shape personal religiosity. 


\subsection{Limitations and Future Studies}

Future theoretical work would gain from attempts to synthesize both structural and psychological perspectives, as this paper has done. Although our study contributes to the scholarship on emerging adulthood, religiosity and civic engagement, it is important to acknowledge several limitations. First, our study is limited by a lack of specific indicators of religious salience and other forms of subjective religiosity. While we recognize this as a study limitation, we suggest that this could pave the way for future research. Second, because our study utilized a cross-sectional design, we are unable to establish causal relationships between various religious factors and volunteerism. Moreover, though our childhood religiosity was gauged via a series of retrospective questions, we caution readers to refrain from drawing strict causal conclusions without panel data. Third, our study does not contain qualitative information from in depth interviews; as such, future research should employ mixed methods to better examine and understand motivations, either religious or secular, for volunteering. Fourth, future research could explore if the religiosity-civic engagement link, as we uncovered in the present study, exists for emerging adults who have either (1) never attended college; or (2) currently hold college degrees but juggle competing commitments such as careers and family life. Finally, previous studies indicate that parental volunteering and volunteering during grade school are also significant predictors of emerging adulthood volunteerism [94]. Future studies should consider including these measures as additional predictors of adulthood volunteerism.

In closing, we are mindful of the fact that college students represent a distinct minority population among all American young adults. Therefore, the motivations to volunteer may be distinct from individuals at different stages of the life course. On the one hand, college students may be concerned with more utilitarian aspects of volunteerism, such as accumulating experiences that may translate to later employment skills and competencies, or as a means to strengthen one's future employment resume. On the other hand, college students have been shown to often hold more idealistic views regarding social issues and perceived injustices. For these reasons, examining patterns of volunteerism among emerging adults can greatly enhance the body of scholarship on civic engagement. Our study is a small step in this direction.

Author Contributions: Reed DeAngelis collected original survey data and co-authored the initial draft with Gabriel Acevedo. Xiaohe Xu performed additional statistical analyses and substantially revised the original manuscript.

Conflicts of Interest: The authors declare no conflict of interest.

\section{References}

1. Jennifer L. Tanner. "Recentering During Emerging Adulthood: A Critical Turning Point in Life Span Human Development." In Emerging Adults in Aermica: Coming of Age in the 21st Century. Edited by Jeffrey J. Arnett and Jennifer L. Tanner. Washington: American Psychological Association, 2006.

2. Christian Smith, and Patricia Snell. Souls in Transition: The Religious and Spiritual Lives of Emerging Adults. New York: Oxford University Press, 2009.

3. Jonathan P. Hill, and Kevin R. Den Dulk. "Religion, Volunteering, and Educational Setting: The Effect of Youth Schooling Type on Civic Engagement." Journal for the Scientific Study of Religion 52 (2013): 179-97. [CrossRef]

4. Neal Krause, and Christopher G. Ellison. "Parental Religious Socialization Practices and Self-Esteem in Late Life." Review of Religious Research 49 (2007): 109-27.

5. Jerry Z. Park, and Elaine Howard Ecklund. "Negotiating Continuity: Family and Religious Socialization for Second-Generation Asian Americans." The Sociological Quarterly 48 (2007): 93-118. [CrossRef]

6. Alexis de Tocqueville. (1885) 1989. Democracy in America. New York: Harper Collins.

7. Gerald Gamm, and Robert D. Putnam. "The growth of voluntary associations in America, 1840-1940." Journal of Interdisciplinary History 29 (1999): 511-57. [CrossRef]

8. Robert D. Putnam. “Bowling Alone: America's Declining Social Capital." Journal of Democracy 6 (1995): 65-78. [CrossRef] 
9. Robert D. Putnam. "Tuning In, Tuning Out: The Strange Disappearance of Social Capital in America." Ps-Political Science \& Politics 28 (1995): 664-83. [CrossRef]

10. Robert D. Putnam. Bowling Alone: The Collapse and Revival of American Community. New York: Simon \& Schuster, 2000.

11. Dietlind Stolle, and Marc Hooghe. "Review article: Inaccurate, exceptional, one-sided or irrelevant? The debate about the alleged decline of social capital and civic engagement in western societies." British Journal of Political Science 35 (2005): 149-67. [CrossRef]

12. Russell J. Dalton. "Citizenship norms and the expansion of political participation." Political Studies 56 (2008): 76-98. [CrossRef]

13. John Wilson. "Volunteering." Annual Review of Sociology 26 (2000): 215-40. [CrossRef]

14. Paul A. Djupe, Anand E. Sokhey, and Christopher P. Gilbert. "Present but Not Accounted for? Gender Differences in Civic Resource Acquisition." American Journal of Political Science 51 (2007): 906-20. [CrossRef]

15. Jill E. Fuller. "Equality in Cyberdemocracy? Gauging Gender Gaps in On-line Civic Participation." Social Science Quarterly 85 (2004): 938-57. [CrossRef]

16. Michael A. Lewis, and Eri Noguchi. "The Female Corp of Volunteers: How Gender and Labor Supply Interact to Affect Civic Participation." Race, Gender E Class 13 (2006): 255-67.

17. Ian A. Gutierrez, and Jacqueline S. Mattis. "Factors Predicting Volunteer Engagement among Urban-Residing African American Women." Journal of Black Studies 45 (2014): 599-619. [CrossRef]

18. Belinda C. Lum, and Michelle M. Jacob. "University-Community Engagement, Axes of Difference \& Dismantling Race, Gender, and Class Oppression." Race, Gender \& Class 19 (2012): 309-24.

19. Jan E. Mutchler, Jeffrey A. Burr, and Francis G. Caro. "From paid worker to volunteer: Leaving the paid workforce and volunteering in later life." Social Forces 81 (2003): 1267-93. [CrossRef]

20. Shu-Chun Chang, Chen-Ling Fang, Yi-Chang Ling, and Bi-Kun Tsai. "Effects of Socioeconomic Status on Leisure Volunteering Constraint: A Structural Equation Model." Social Behavior E Personality: An International Journal 39 (2011): 477-89. [CrossRef]

21. David H. Smith. "Determinants of Voluntary Association Participation and Volunteering: A Literature Review." Nonprofit and Voluntary Sector Quarterly 23 (1994): 243-63. [CrossRef]

22. Norman H. Nie, Jane Junn, and Kenneth Stehlik-Barry. Education and Democratic Citizenship in America. Chicago: University of Chicago Press, 1996.

23. Maurice Gesthuizen, and Peer Scheepers. "Educational Differences in Volunteering in Cross-National Perspective: Individual Contextual Explanations." Nonprofit and Voluntary Sector Quarterly 41 (2012): 58-81. [CrossRef]

24. Marc A. Musick, John Wilson, and William B. Bynum. “Race and Formal Volunteering: The Differential Effects of Class and Religion." Social Forces 78 (2000): 1539-70. [CrossRef]

25. David H. Smith, and Burt R. Baldwin. "Parental Socialization, Socioeconomic Status, and Volunteer Organization Participation." Journal of Voluntary Action Research 3 (1974): 59-66.

26. Susan Eckstein. "Community as Gift-Giving: Collectivistic Roots of Volunteerism." American Sociological Review 66 (2001): 829-51. [CrossRef]

27. Sally K. Gallagher. "Doing Their Share: Comparing Patterns of Help Given by Older and Younger Adults." Journal of Marriage and Family 56 (1994): 567-78. [CrossRef]

28. Cassie L. Barnhardt, Jessica E. Sheets, and Kira Pasquesi. "You Expect What? Students' Perceptions as Resources in Acquiring Commitments and Capacities for Civic Engagement." Research in Higher Education 56 (2015): 622-44. [CrossRef]

29. Elizabeth Weiss Ozorak. "Love of God and Neighbor: Religion and Volunteer Service among College Students." Review of Religious Research 44 (2003): 285-99. [CrossRef]

30. Kraig Beyerlein, and John R. Hipp. "From Pews to Participation: The Effect of Congregation Activity and Context on Bridging Civic Engagement." Social Problems 53 (2006): 97-117. [CrossRef]

31. Kraig Beyerlein, and David Sikkink. "Sorrow and Solidarity: Why Americans Volunteered for 9/11 Relief Efforts." Social Problems 55 (2008): 190-215. [CrossRef]

32. John Wilson, and Marc Musick. "Who Cares? Toward an Integrated Theory of Volunteer Work." American Sociological Review 62 (1997): 694-713. [CrossRef]

33. Pui-Yan Lam. "As the Flocks Gather: How Religion Affects Voluntary Association Participation." Journal for the Scientific Study of Religion 41 (2002): 405-22. [CrossRef] 
34. Valerie A. Lewis, Carol A. MacGregor, and Robert D. Putnam. "Religion, Networks, and Neighborliness: The Impact of Religious Social Networks on Civic Engagement." Social Science Research 42 (2013): 331-46. [CrossRef] [PubMed]

35. Elton F. Jackson, Mark D. Bachmeier, James R. Wood, and Elizabeth A. Craft. "Volunteering and Charitable Giving: Do Religious and Associational Ties Promote Helping Behavior? " Nonprofit and Voluntary Sector Quarterly 24 (1995): 59-78.

36. Jerry Z. Park, and Christian Smith. “'To Whom Much Has Been Given...': Religious Capital and Community Voluntarism among Churchgoing Protestants." Journal for the Scientific Study of Religion 39 (2000): 272-86. [CrossRef]

37. Brett G. Scharffs. “Volunteerism, Charitable Giving, and Religion: The U.S. Example." Review of Faith E International Affairs 7 (2009): 61-67. [CrossRef]

38. John Wilson, and Thomas Janoski. "The Contribution of Religion to Volunteer Work." Sociology of Religion 56 (1995): 137-52. [CrossRef]

39. Gabriel A. Acevedo. "Collective Rituals or Private Practice in Texas? Assessing the Impact of Religious Factors on Mental Health." Review of Religious Research 52 (2010): 188-206.

40. Pamela Paxton, Nicholas E. Reith, and Jennifer L. Glanville. "Volunteering and the Dimensions of Religiosity: A Cross-National Analysis." Review of Religious Research 56 (2014): 597-625. [CrossRef]

41. Marc A. Musick, and John Wilson. "Volunteering and depression: The role of psychological and social resources in different age groups." Social Science \& Medicine 56 (2003): 259-69. [CrossRef]

42. Warren B. Hrung. "After-Life Consumption and Charitable Giving." The American Journal of Economics and Sociology 63 (2004): 731-45. [CrossRef]

43. Jonathan Rosborough. "A Theory of Congregational Giving." Journal of Public Economic Theory 17 (2015): 270-95. [CrossRef]

44. David Horton Smith. "Altruism, Volunteers, and Volunteerism." Nonprofit and Voluntary Sector Quarterly 10 (1981): 21-36. [CrossRef]

45. Steve Bruce. "Religion and Rational Choice: A Critique of Economic Explanations of Religious Behavior." Sociology of Religion 54 (1993): 193-205. [CrossRef]

46. Mark Chaves. "On the Rational Choice Approach to Religion." Journal for the Scientific Study of Religion 34 (1995): 98-104. [CrossRef]

47. Lionel Prouteau, and François-Charles Wolff. “On the relational motive for volunteer work." Journal of Economic Psychology 29 (2008): 314-35. [CrossRef]

48. Lynette S. Unger. "Altruism as a motivation to volunteer." Journal of Economic Psychology 12 (1991): 71-100. [CrossRef]

49. Zandra N. Quiles, and Jane Bybee. "Chronic and Predispositional Guilt: Relations to Mental Health, Prosocial Behavior, and Religiosity." Journal of Personality Assessment 69 (1997): 104-26. [CrossRef] [PubMed]

50. Peggy A. Thoits, and Lyndi N. Hewitt. "Volunteer Work and Well-Being." Journal of Health and Social Behavior 42 (2001): 115-31. [CrossRef] [PubMed]

51. Nancy T. Ammerman. "Religious narratives, community service, and everyday public life." In Taking Faith Seriously. Edited by Mary Jo Bane, Brent Coffin and Richard Higgins. Cambridge: Harvard University Press, 2005, pp. 146-74.

52. Joseph B. Johnston. "Religion and Volunteering Over the Adult Life Course." Journal for the Scientific Study of Religion 52 (2013): 733-52. [CrossRef]

53. Marc A. Musick, and John Wilson. Volunteers: A Social Profile. Bloomington: Indiana University Press, 2008.

54. Chaeyoon Lim, and Carol Ann MacGregor. "Religion and Volunteering in Context: Disentangling the Contextual Effects of Religion on Voluntary Behavior.” American Sociological Review 77 (2012): 747-79. [CrossRef]

55. Francesca Borgonovi. "Doing well by doing good. The relationship between formal volunteering and self-reported health and happiness." Social Science E Medicine 66 (2008): 2321-34. [CrossRef] [PubMed]

56. Lona H. Choi. "Factors Affecting Volunteerism among Older Adults." Journal of Applied Gerontology 22 (2003): 179-96. [CrossRef]

57. Barbara R. McIntosh, and Nicholas L. Danigelis. "Race, gender, and the relevance of productive activity for elders' affect." The Journals of Gerontology Series B: Psychological Sciences and Social Sciences 50 (1995): S229-39. [CrossRef] 
58. John Wilson, and Marc Musick. "The Contribution of Social Resources to Volunteering." Social Science Quarterly 79 (1998): 799-814.

59. Albert Bandura. Social Learning Theory. Englewood Cliffs: Prentice-Hall, 1977.

60. Thomas G. O'Connor, Carla Matias, Annabel Futh, Grace Tantam, and Stephen Scott. “Social Learning Theory Parenting Intervention Promotes Attachment-Based Caregiving in Young Children: Randomized Clinical Trial." Journal of Clinical Child E Adolescent Psychology 42 (2013): 358-70. [CrossRef] [PubMed]

61. Ronald L. Simons, Les B. Whitbeck, Rand D. Conger, and Katherine J. Conger. "Parenting factors, social skills, and value commitments as precursors to school failure, involvement with deviant peers, and delinquent behavior." Journal of Youth and Adolescence 20 (1991): 645-64. [CrossRef] [PubMed]

62. E. Gil Clary, and Jude Miller. "Socialization and Situational Influences on Sustained Altruism." Child Development 57 (1986): 1358-69. [CrossRef] [PubMed]

63. Michela Lenzi, Alessio Vieno, Massimo Santinello, Maury Nation, and Adam Voight. "The Role Played by the Family in Shaping Early and Middle Adolescent Civic Responsibility." The Journal of Early Adolescence 34 (2014): 251-78. [CrossRef]

64. Rene Bekkers. "Intergenerational Transmission of Volunteering." Acta Sociologica 50 (2007): 99-114. [CrossRef]

65. Sarah Mustillo, John Wilson, and Scott M. Lynch. "Legacy Volunteering: A Test of Two Theories of Intergenerational Transmission." Journal of Marriage and Family 66 (2004): 530-41. [CrossRef]

66. Amanda Moore McBride, Margaret S. Sherraden, and Suzanne Pritzker. "Civic Engagement among Low-Income and Low-Wealth Families: In Their Words." Family Relations 55 (2006): 152-62. [CrossRef]

67. Fengyan Tang. "What Resources Are Needed for Volunteerism? A Life Course Perspective." Journal of Applied Gerontology 25 (2006): 375-90. [CrossRef]

68. Daniel T. Lichter, Michael J. Shanahan, and Erica L. Gardner. "Helping Others?: The Effects of Childhood Poverty and Family Instability on Prosocial Behavior." Youth \& Society 34 (2002): 89-119. [CrossRef]

69. Jeffrey J. Arnett. "Emerging Adulthood: A Theory of Development from the Late Teens through the Twenties." American Psychologist 55 (2000): 469-85. [CrossRef] [PubMed]

70. Jeffrey J. Arnett. Emerging Adulthood: The Winding Road from the Late Teens through the Twenties. New York: Oxford University Press, 2006.

71. Manfred H. M. van Dulmen. “Emerging Adulthood-The Journal." Emerging Adulthood 1 (2013): 3-4. [CrossRef]

72. Naomi N. Duke, Carol L. Skay, Sandra L. Pettingell, and Iris W. Borowsky. "From Adolescent Connections to Social Capital: Predictors of Civic Engagement in Young Adulthood." Journal of Adolescent Health 44 (2009): 161-68. [CrossRef] [PubMed]

73. Richard M. Clerkin, Sharon R. Paynter, and Jami Kathleen Taylor. "Public Service Motivation in Undergraduate Giving and Volunteering Decisions." American Review of Public Administration 39 (2009): 675-98. [CrossRef]

74. James Youniss, Jeffrey A. McLellan, and Miranda Yates. "Religion, community service, and identity in American youth." Journal of Adolescence 22 (1999): 243-53. [CrossRef] [PubMed]

75. Christian Smith. "Religious Participation and Network Closure among American Adolescents." Journal for the Scientific Study of Religion 42 (2003): 259-67. [CrossRef]

76. Christian Smith, and Melissa Denton. Soul Searching: The Religious and Spiritual Lives of American Teenagers. New York: Oxford University Press, 2005.

77. Kathryn A. Johnson, Adam B. Cohen, and Morris A. Okun. "Intrinsic Religiosity and Volunteering During Emerging Adulthood: A Comparison of Mormons with Catholics and Non-Catholic Christians." Journal for the Scientific Study of Religion 52 (2013): 842-51. [CrossRef]

78. Edmund Forst, and Rose Marie Healy. "Correlations among Religion, Commitment, And Volunteer Participation." Psychological Reports 69 (1991): 1224. [CrossRef]

79. Troy Gibson. “Religion and civic engagement among America's youth." The Social Science Journal 45 (2008): 504-14. [CrossRef]

80. Richard K. Caputo. "Religious Capital and Intergenerational Transmission of Volunteering as Correlates of Civic Engagement." Nonprofit and Voluntary Sector Quarterly 38 (2009): 983-1002. [CrossRef] 
81. University of Texas at San Antonio. “The University of Texas at San Antonio Fall Semester 2015 Student Profile: Census Day_Preliminary Paid Report." 2015. Available online: http:/ /www.utsa.edu/registrar/ enrollment.html (accessed on 3 December 2015).

82. Brian Streensland, Jerry Z. Park, Mark D. Regnerus, Lynn D. Robinson, W. Bradford Wilcox, and Robert D. Woodberry. "The measure of American religion: Toward improving the state of the art." Social Forces 79 (2000): 291-318. [CrossRef]

83. Meredith McGinly, Sharon Lipperman-Kreda, Hilary F. Byrnes, and Gustavo Carlo. “Parental, social and dispositional pathways to Israeli adloescents' volunteering." Journal of Applied Developmental Psychology 31 (2010): 386-93. [CrossRef]

84. Amanda Shantz, Tina Saksida, and Kerstin Alfes. "Dedicating time to volunteering: Values, engagement, and commitment to beneficiaries." Applied Psychology 63 (2014): 671-97. [CrossRef]

85. Joonmo Son, and John Wilson. "Using Normative Theory to Explain the Effect of Religion and Education on Volunteering." Sociological Perspectives 55 (2012): 473-99.

86. Kevin F. Forbes, and Ernest M. Zampelli. “Volunteerism: The Influences of Social, Religious, and Human Capital." Nonprofit and Voluntary Sector Quarterly 43 (2014): 227-53. [CrossRef]

87. Stephen M. Merino. "Religious Social Networks and Volunteering: Examining Recruitment via Close Ties." Review of Religious Research 55 (2013): 509-27. [CrossRef]

88. Lisa A. Keister. "Religion and Wealth: The Role of Religious Affiliation and Participation in Early Adult Asset Accumulation." Social Forces 82 (2003): 175-207. [CrossRef]

89. Christian Smith. "Theorizing Religious Effects among American Adolescents." Journal for the Scientific Study of Religion 42 (2003): 17-30. [CrossRef]

90. David Caplovitz, and Fred Sherrow. The Religious Drop-outs: Apostasy among College Graduates. Beverly Hills: Sage, 1977.

91. Jonathan P. Hill. "Higher Education as Moral Community: Institutional Influences on Religious Participation During College." Journal for the Scientific Study of Religion 48 (2009): 515-34. [CrossRef]

92. Philip F. Jacob. Changing Values in College. New York: Wiley, 1958.

93. Kenneth A. Feldman, and Theodore M. Newcomb. The Impact of College on Students. Piscataway: Transaction Publishers, 1969.

94. Thomas Janoski, and John Wilson. "Pathways to Voluntarism: Family Socialization and Status Transmission Models." Social Forces 74 (1995): 271-92. [CrossRef] 